\title{
ANALISA PENDAPATAN USAHA NELAYAN PERAHU MOTOR DI DESA SELUBUK KECAMATAN AIR NAPAL KABUPATEN BENGKULU UTARA
}

\author{
Bambang Sumantri ${ }^{1}$ \\ Bian Suwarli 2 \\ 1 Staff Pengajar Jurusan Sosial Ekonomi Pertanian Fak.Pertanian UNIB \\ 2 Alumni Jurusan Sosial Ekonomi Pertanian Fak.Pertanian UNIB
}

\begin{abstract}
Fishery sector represent very important sector to be developed beside agricultural sector of ranch and food crop. Development in fishery sector to date remain to be aimed at a contribution improvement sub of fishery sector in guaranting available of protein hewani food substance, industrial raw material, improvement export, pushing opportunity and employment extension try, increased fisherman earnings and also support area development. this Spacious college aim to to know mean earnings accepted by speed boat fisherman. activity college field executed in Countryside of Deep Hollow of Subdistrict Irrigate Napal Regency North Bengkulu. Analysis Method used is earnings analysis. Result college field indicate that earnings flatten to flatten month fisherman of speed boat is Rp1.586.001,00. This Circumstance mirror that individualness earnings accepted by fisherman a high relative.
\end{abstract}

Key word : income, fisherman,

\section{PENDAHULUAN}

Sektor perikanan merupakan sektor yang sangat penting untuk dikembangkan disamping sektor pertanian tanaman pangan dan peternakan. Pembangunan di sektor perikanan sampai saat ini tetap diarahkan pada peningkatan kontribusi sub sektor perikanan dalam menjamin tersedianya bahan pangan protein hewani, bahan baku industri, peningkatan ekspor, mendorong perluasan lapangan kerja dan kesempatan berusaha, meingkatkan pendapatan nelayan serta menunjang pembangunan daerah. Pembangunan sektor perikanan terutama diarahkan pada pengembangan produksi perikanan laut dan budidaya. Selain faktor sumber daya alam, faktor lain yang diperlukan dalam penguasaan perikanan adalah pemanfaatan SDM (fisik, mental, keterampilan dan keahlian), modal dan kemampuan teknologi yang baik. Walaupun sebenarnya lautnya lebih luas dari pada daratan yang ada, tetapi hasil dari laut sangat minim sekali. Ini karena laut kita adalah samudera Indonesia yang masih sangat ganas. Nelayan yang mengolah hasil laut juga masih tradisional.

Salah satu kendala yang mendasar dalam menggunakani potensi kelautan seperti masyarakat nelayan adalah menggunakan peralatan sederhana sehingga mereka masih dapat digolongkan sebagai masyarakat yang berpenghasilan rendah. Perahu yang digunakan oleh 
nelayan beraneka ragam jenisnya. Namun studi ini secara khusus untuk menganalisa pendapatan rumah tangga nelayan yang menggunakan perahu motor / motor temple. Dengan pertimbangan bahwa jumlah perahu motor yang digunakan oleh nelayan cukup beragam khususnya di Air Napal. Tulisan ini membahas pendapatan rata-rata yang diterima oleh nelayan perahu motor.

\section{METODOLOGI PENELITIAN}

Penentuan lokasi dilakukan secara sengaja yaitu didesa Selubuk Kecamatan Air Napal Kabupaten Bengkulu Utara. Pemilihan lokasi ini didasarkan pada pertimbangan bahwa desa tersebut merupakan salah satu sentra produksi ikan laut di Kecamatan Air Napal yang dilakukan pada bulan April - Mei 2005. Data yang diambil berupa data primer dan data sekunder. Data primer diperoleh dari responden melalui wawancara dengan orang orang yang ada hubungannya dengan nelayan pemilik yang menggunakan perahu motor. Sedangkan data sekunder diperoleh dari suatu sumber yang yang telah mengumpulkan data tersebut yaitu melalui lembaga atau instansi pemerintah, perpustakaan dan lain lain yang ada kaitannya. Analisis Pendapatan Nelayan secara matematis perhitungan pendapatan nelayan adalah selisih total penerimaan terhadap total pengeluaran nelayan

\section{HASIL DAN PEMBAHASAN}

Rata rata umur nelayan adalah 46,5 tahun dengan kisaran 27- 76 tahun. Menurut Nurdin (1981) bahwa umur 15 sampai 64 tahun merupakan usia produktif. Ini berarti 96 \% nelayan yang ada di Desa Selubuk berada pada usia produktif sehingga memungkinkan nelayan bekerja secara optimal untuk mengelolah usahanya. Tingkat pendidikan formal nelayan relatif tinggi, dengan tingkat pendidikan rata rata 11,9 tahun dengan kisaran $6-7$ tahun. Tingkat pendidikan formal berhubungan positif dengan kemampuan nelayan berkomunikasi baik melalui lisan maupun tulisan. Semakin tinggi tingkat pendidikan formal nelayan, diharapkan masukan masukan teknologi yang diperlukan baik melalui siaran radio, televisi, atau media informasi lainnya cepat diterima oleh nelayan (Kartasapoetra, 1988). Selain itu tentu saja tingkat pendidikan formal ini akan mempengaruhi nelayan dalam mengelolah usahanya.

Disamping itu dalam hal kenelayanan pada dasarnya nelayan telah memiliki pengalaman yang cukup yang diperoleh dari orang tuanya (turun temurun) ataupun daru kerabat kerabatnya. Pengalaman ini sangat menunjang/ membantu dalam hal pengembangan usaha perikanan tangkap yang dikelolah. Jumlah tanggungan keluarga nelayan rata rata 4,3 orang 
dengan kisaran 2-7 orang. Jumlah tanggungan ini relatif lebih rendah. Besar kecilnya jumlah tanggungan keluarga akan mempengaruhi besar kecilnya pendapatan dan pengeluaran dalam keluarga tersebut

Nelayan untuk memenuhi kebutuhan hidupnya mengandalkan hasil tangkapannya. Dengan kata lain nelayan tidak mempunyai pekerjaan sampingan. Pekerjaan yanmg dilakukan pada umumnya masih berada diseputar perikanan seperti menjual hasil tangkapan ikan atau mengurus keperluan lain yang masih ada hubungannya dengan usaha perikanan. Jumlah nelayan pemilik perahu motor yang dilengkapi dengan alat jarrng insang hanyut (drift gill net) sampai tahun 2005 adalah 26 orang dengan jumlah perahu motor keseluruhan adalah 36 buah perahu motior. Rata rata jumlah perahu motor yang dimiliki nelayan adalah 1 buah perahu motor dengan kisaran 1 - 3 perahu motor.

Nelayan pemilik pada umumnya dalam mengoperasikan perahu motornya memperkerjakan tenaga kerja dari luar keluarga, walaupun ada dari anggota keluarga nelayan pemilik perahu motor yang cukup mampu mengoperasiakan perahunya tetapi anggota keluarga nelayan pada umumnya bekerja disektor lain. Untuk mendapatkan tenaga kerja, nelayan tidak mengalami kesulitan karena tenaga kerja yang mereka butuhkan cukup tersedia didaerah ini.

\section{Biaya Produksi}

Biaya produksi merupakan kiorbanan yang dikeluarkan oleh nelayan dalam melakukan kegiatan produksi. Biaya preoduksi yang diperhitungkan adalah semua biaya yang dikeluarkan agar diperoleh produk yaitu ikan sampai ikan itu laku terjual ketangan pedagang pengumpul. Biaya yang dikeluarkan oleh nelayan terdiri dari biaya penyusutan peralatan, biaya operasional dan biaya tenaga kerja.

\section{Biaya Penyusutan}

Biaya penyusutan peralatan nelayan perahu motor diperhitungkan dari penggunaan modal tetap yang digunakan seperti perahu, mesin, jarring, lampu perahu, dan tali yaitu harga pembelian dibagi dengan umur ekonomis. Biaya penyusutan atas penggunaan modal tetap rata rata perbulan adalah Rp 259.181 dengan kisaran Rp120.555,56 - 713.083,35 rata rata pembelian bodi perahu adalah Rp 10.019.230,77 dengan kisaran antara Rp 3500.000 - Rp 20.000.000. Biaya penyusutan perahu perbulannya adalah Rp 103.611,11 .Pembelian perahu di lakukan di Desa Selubuk karena di Desa Selubuk terdapat tempat pembuatan perahu yang melayani nelayan yang ingin membeli perahu, walaupun ada juga nelayan yang membeli perahu 
bekas dari nelayan lain. Daya tahan (umur ekonomis) perahu ini rata rata 152,31 bulan (13 tahun) dengan 120 - 180 bulan (10 - 15 tahun )

Mesin yang digunakan pada umumnya bermerek Yanmar dengan kekuatan (power knot) yang bermacam macam. Semakin besar ukuran perahu, maka kekuatan mesin yang dipakai semakin besar. Harga mesin yang digunakan rata rata Rp 6.692.307,69 dengan kisaran antara Rp 1000.000,00 - Rp 20.000.000,00. Daya tahan mesin dapat mencapai rata rata 205,38 bulan atau 17 tahun dengan kisaran 120 - 240 bulan (10-20 tahun), sedangkan biaya penyusutannya perbulannya adalah Rp 7.384.615.38

Harga seperangkat / unit jaring yang digunakan rata rata Rp 239.423,08 dengan kisaran antara Rp 100.000,00 - Rp 700.000,00. Biaya penyusutan jaring adalah Rp 6046,61. Seperangkat jaring yang digunakan terdiri dari rata rata 51,54 piece dengan kisaran $40-70$ piece. Tiap tiap piece berukuran panjang antara 30-40 meter dengan lebar antara 7-8 meter dengan ukuran mata jaring 3,5 inchi dan bahan pokok untuk pembuatan jaring adalah benang nilon. Daya tahan jaring ini adalah 212,31 bulan (18 tahun) dengan kisaran antara $120-240$ bulan (10-20 tahun). Pada jaring ini juga dilengkapi dengan alat pengapung yang diletakkan diujungnya. Hal ini dilakukan agar jaring yang dipasang tidak dilanggar oleh perahu lain. Jumlah alat pengapung jaring yang digunakan adalah 2 buah. Perlengkapan perahu yang lain yang dibawa adalah peti/bak ikan pada umumnya disesuaikan dengan ukuran perahu, dimana rata rata peti ikan yang dibawa berjumlah satu buah untuk setiap perahu motor. Harga rata rata pembelian peti atau bak ikan adalah Rp 1. 336.538,00 dengan kisaran antara Rp 250.000,00 Rp 5000.000,00 dan rata rata daya tahannya adalah 60 bulan (5 tahun) dengan biaya penyusutan perbulannya adalah sebesar Rp 22.275,64.

Peralatan lainnya adalah tali, dimana pembelian tali ini diperhitungkan beratnya dalam $\mathrm{kg}$. Rata rata tali yang digunakan oleh nelayan beratnya 10 - $20 \mathrm{~kg}$ dan harga rata rata perkg adalah $\operatorname{Rp} 25000,00$. Daya tahan rata rata tali adalah 120 bulan (10 tahun). Biaya penyusutan tali perbulannya adalah Rp 9.415,06. Rata rata jerigen air yang digunakan berjumlah 20 buah dengan kisaran 15 - 25 buah. Harga rata rata jerigen adalah Rp 10.500,00 dengan kisaran Rp 4000,00 - Rp 20.000 dan daya tahannya 60 bulan (5 tahun). Rata rata jerigen minyak yang di bawa adalah 1 - 2 buah, dengan harga rata rata per jerigen adalah Rp 27.462,00 dengan kisaran $\operatorname{Rp~15.000,00~-~Rp~60.000,00~dan~daya~tahan~rata~rata~107,54~(9~tahun)~bulan~dengan~}$ kisaran antara 60 - 120 bulan (5-10 tahun). Biaya penyusutan jerigen air dan jerigen minyak 
perbulannya masing masing sebesar Rp 3.445,51dan Rp 395,78. Rata rata jumlah lampu perahu yang digunakan adalah 3 - 5 buah. Harga rata rata lampu adalah Rp 5000,00. Daya tahan lampu perahu adalah rata rata 24 bulan (0,2 tahun) dengan kisaran 24 bulan. Biaya penyusutan lampu perbulannya dalah sebesar Rp 929,49.

\section{Biaya Operasioanal}

Biaya operasional terdiri dari biaya ransum, minyak oli, minyak solar, es balok, air bersih, biaya perawatan kapal, mesin jaring, dan biaya administrasi. Biaya operasional rata rata yang dikeluarkan perbulannya adalah Rp 4.619.423,08 dengan kisaran antara Rp 27.37500 - Rp 6.600.000,00. Biaya ransum pertripnya adalah Rp 569.230,77 dengan kisaran antara Rp $300.000,00$ - Rp 1000.000. Dalam satu bulan rata rata nelayan melaut 3 kali atau 3 trip. Rata rata biaya yang dikeluarkan untuk ransum perbulannya adalah $\mathrm{Rp} 1.707 .692,31$ dengan kisaran antara Rp 900.000 - 3000.000.

Rata rata biaya minyak oli yang digunakan pertripnya adalah Rp 75000,00 dengan kisaran Rp 40.000,00 - Rp 100.000,00. Biaya penggunaan minyak oli perbulannya adalah Rp $225.000,00$ dengan kisaran antara Rp 120.000,00 - Rp 300.00,00. Sedangkan harga perliternya adalah Rp 10.000,00.

Bahan bakar lain yang di gunakan oleh perahu motor adalah minyak solar dengan rata rata penggunaan perbulannya adalah 946,15 liter dengan kisaran antara 600 - 1200 liter. Harga perliternya adalah $\mathrm{Rp} \quad 2.000,00$. Semakin lama dan semakin jauh nelayan mengoperasikan perahunya maka bahan bakar yang di gunakan akan semakin banyak. Rata rata biaya yang dikeluarkan untuk bahan bahan bakar solar adalah Rp1.892.307,69 dengan kisaran antara Rp 1.200.000,00 - Rp 2.400.000,00.

Agar hasil tangkapan yang didapat tidak lekas membusuk, nelayan membawa es balok. Jumlah es balok yang dibawa pertripnya adalah 26 balok dengan harga rata rata perbaloknya adalah $\mathrm{Rp} 8.500,00$. Rata rata total biaya yang dikeluarkan untuk es balok perbulan adalah $\mathrm{Rp}$ 657.115,38 dengan kisaran antara Rp 382.500,00 - Rp 892. 500,00. Es balok ini langsung diantar oleh pedagangnya ketempat dermaga . Air bersih yang digunakan diperoleh dari PAM. Besarnya biaya yang dikeluarkan untuk keperluan air bersih pertripnya adalah $\mathrm{Rp} 20.000,00$ dengan kisaran antara Rp15.000,00 - Rp 25.000,00. Rata rata biaya air bersih perbulannya adalah $\mathrm{Rp} 60.000,00$ dengan kisaran antara Rp 45.000,00 - Rp 75.000,00. 
Perawatan perahu dilakukan pada saat docking. Dalam satu bulan rata rata satu kali docking. Biaya yang dikeluarkan untuk perawatan perahu dalam sebulan adalah $\mathrm{Rp} 176.564,00$ dengan kisaran antara $R p 83.400,00$ - Rp 249.000,00. Sedangkan biaya perawatan mesin perbulannya adalah Rp 196.754,00 dengan kisaran antara Rp 83.400,00 - Rp 333000,00. Perawatan jaring dilakukan setiap trip karena dalam pengoperasian jaring ada beberapa bagian jaring yang rusak. Biasanya nelayan membawa beberapa gulung benang nilon dimana harga rata rata pergulungnya adalah $\mathrm{Rp} 2 \cdot 300,00$. Biaya yang dikeluarkan untuk perawatan jaring adalah $\operatorname{Rp} 2.500,00$ pertrip dan $\mathrm{Rp} 7.500,00$ perbulan. Untuk biaya adminstrasi diberikan setelah operasi penangkapan ikan yang diberikan kepada petugas pelabuhan. Biaya administrasi perbulannya adalah $\mathrm{Rp} 60.000,00$. Sedangkan biaya pertripnya adalah sebesar Rp 20.000,00/kapal.

Semua biaya yang dikeluarkan dalam proses produksi ditanggung oleh nelayan pemilik, sedangkan tenaga kerja (ABK) hanya mengoperasikan perahu saja. Modal yang didapat beerasal dari modal sendiri atau terkadang nelayan pemilik meminjam dengan nelayan lain. Peminjaman ini tidak dikenakan bunga dan waktu pengembalian tidak ditentukan.

\section{Tenaga Kerja}

Tenaga kerja dalam usaha penangkapan ikan adalah tenaga kerja laki laki.. Umumnya pemilik kapal mempekerjakan tenaga kerja luar keluarga dan dalam keluarga di samping pemilik kapal ikut juga dalam penangkapan ikan dilaut. Tenaga kerja rata rata perkapal adalah 5 orang.

Tenaga kerja yang digunakan ini kerjanya terbagi bagi dalam beberapa kegiatan., ada yang bertugas sebagai pengemudi perahu dan ada yang mengoperasikan alat tangkap dimana beberapa orang berusaha menarik jaring dan sebagian melepaskan ikan dijaring, Pada waktu senggang $A B K$ menggunakan waktunya untuk memperbaiki jaring apabila ada jaring yang rusak.

Biaya atau upah tenaga kerja dihitung dengan cara keuntungan dibagi dua, sebagian untuk pemilik perahu dan sebagian lagi untuk tenaga kerja secara keseluruhan dibagi sama besar. Biaya rata rata tenaga kerja pertripnya adalah Rp 834.999,08 dengan kisaran Rp $541.829,00$ - Rp 1.129.158,00. Dengan demikian biaya tenaga kerja yang dikeluarkan dalam sebulan apabila jumlah penerimaan dan biaya total relatif tetap adalah $\operatorname{Rp} 2.504 .997,23$ dengan kisaran antara Rp 859.863,00 - Rp 3.387.474,00. 


\section{Penerimaan dan Pendapatan Usaha Nelayan}

Penerimaan di ukur dalam satuan rupiah berupa nilai dari seluruh ikan yang didapat oleh nelayan. Dalam satu bulan nelayan pergi beroperasi 3 trip/kali. Adapun rata rata penerimaan nelayan pada trip pertama adalah sebesar Rp.2.826.923,00 dengan kisaran antara Rp 2000.000,00 - Rp 4000.000,00, trip kedua sebesar Rp 3.552.615,00 dengan kisaran antara Rp 2.300.000,00 - Rp4.772.500,00 sedangkan trip ketiga adalah sebesar Rp 2.908.923,00 dengan kisaran antara Rp 1530.000,00 - Rp 3.612.500. Apabila jumlah penerimaan dan biaya total yang dikeluakan relatif tetap meskipun ada sedikit perbedaan maka rata rata penerimaan perbulannya adalah $\mathrm{Rp} 9.288 .462,00$ dengan kisaran anatara $\mathrm{Rp} 6000.000,00$ - Rp 12000.000,00.

Pendapatan usaha penangakapan ikan di Desa Selubuk Kecamatan Air Napal dihitung dengan mengurangi total penerimaan dengan total pengeluaran. Adapun total pengeluaran perbulannya adalah $\mathrm{Rp} 7.702 .460,00$. Sehingga pendapatan nelayan dalam setiap bulannya adalah $1.586 .001,00$

Nelayan yang berpendapatan diatas rata rata sebanyak 19 orang atau sebanyak 73,07 $\%$ dari keseluruhan dan yang berpendapatan dibawah rata rata sebanyak 7 orang atau 26,93\% dari keseluruhannya (dapat dilihat pada lampiran 7). Keadaan ini mencerminkan bahwa pendapatan perorangan yang diterima oleh nelayan relatif tinggi. Hal ini berarti penggunaan sarana produksi yang dimilik oleh nelayan sudah optimal.

\section{KESIMPULAN}

Kesimpulan yang dapat diambil adalah pendapatan rata rata nelayan pemilik perahu motor perbulan adalah Rp 1.586.001,00.Desa Selubuk kecamatan Air Napal mempunyai potensi yang baik untuk pengembangan usaha penangkapan ikan khususnya dengan perahu motor. Pengembangan usaha dapat dilakukan dengan jalan penambahan modal khususnya pada peralatan tetap karena peralatan yang dimiliki oleh nelayan masih relatif sederhana sehingga nelayan belum memiliki kepastian pendapatan yang akan diterima.

\section{DAFTAR PUSTAKA}

Azzaino, Z. 1982. Pengantar Tata Niaga Pertanian. Bahan kuliah Jurusan IImu IImu Sosial Ekonomi Pertanian Institut Pertanian Bogor : Bogor

Dinas Perikanan Dati 11 Kotamadia Bengkulu. 1996. Pengembangan Perikanan di Kotamadia Bengkulu.

Hani Diana. 1991. Distribusi Pendapatan Pekerja Sektor Industri Kecil di Kotamadia Bengkulu. Skripsi, Universitas Bengkulu (tidak dipublikasikan)

Hanafiah dan Saefudin. 1983. Tataniaga Hasil Perikanan. Rajawali pers : Jakarta. 
Husen, A. 1991. Manajemen Industri Tuna Pola PIR Sistem Rumpon di Irian Jaya. Fakultas pertanian, Institut Pertanian Bogor : Bogor

Kartasapoetra, G. 1992. Manajemen Pertanian Agribisnis. PT. Bina Aksar : Jakarta

Kotler, Philip. 1993. Manajemen Pemasaran. Edisi Ketujuh Volume Kedua Lembaga Penelitian Fakultas Ekonomi Unversitas Indonesia : Jakarta.

Limbong, W.H. dan P. Sitorus. 1987. Pengantar Tataniaga Pertanian. Jurusan Sosial Ekonomi Pertanian Institut Pertanian Bogor : Bogor

Munzir, M. 1995. Studi Distribusi Penguasaan Unit Usaha Penangkapann Ikan Tonda di Kota Padang. Tesis pada Program Pasca Sarjana Universitas Andalas.

Nurdin, Harto. 1981. Dasar Dasar Demografi. LPFE. Universitas Indonesia : Jakarta

Pramudiasmono,H.G. 1993. Faktor Faktor yang Mempengaruhi Rendahnya Tingkat Kesejahteraan Keluarga Nelayan di Bengkulu. Laporan Penelitian Lembaga Penelitian, Universitas Bengkulu.

Priyono. 1998. Analisa Pendapatan dan Motivasi Jamu Gendong Perantauan Asal Jawa di Kotamamdia Bengkulu. Laporan Penelitian Lembaga Penelitian Fakultas Pertanian Universitas Bengkulu (tidak di publikasikan)

Soekartawi. 1987. Prinsip Dasar Ekonomi Pertanian. Raja Grapfindo Persada : Jakarta.

Supranta, J. 1983. Ekonometrika Buku Satu. Lembaga Penerbit Fakultas Ekonomi Universitas Indonesia : Jakarta.

Susilawati, T.1983. Kedudukan Pertanian Perantara dalam Masyarakat Nelayan di Kabupaten Tanjung Jabun Jambi. Pusat Penelitian dan Pengembangan Pertanian deparetemen Pertanian : Jakarta.

Usman. 1990. Analisa Pengaruh Motivasi Terhadap Semanagat dan Kegairahan Kerja Karyawan pada Kantor Daerah Telepon dan Telegram Kotamadia Bengkulu. Fakultas Ekonomi Universitas Bengkulu (tidak dipublikasikan)

Winardi. 1980. Pengantar Ilmu Ekonomi. Tarsito : Bandung.

Mubyarto,1989. Pengantar Ekonomi Pertanian. LP3ES, Jakarta 